\title{
Disaster Risk Reduction Education: Tensions and Connections with Sustainable Development Goals
}

\author{
Valeria M. Cabello ${ }^{1, *(1)}$, Karina D. Véliz ${ }^{2}$, Ana M. Moncada-Arce ${ }^{3}$, María Irarrázaval García-Huidobro ${ }^{4}$ \\ and Felipe Juillerat ${ }^{5}$ \\ 1 Facultad de Educación and Research Center for Integrated Disaster Risk Management (CIGIDEN), \\ Pontificia Universidad Católica de Chile, Santiago 7820436, Chile \\ 2 School of Industrial Engineering, Universidad Diego Portales, Santiago 8370190, Chile; karina.veliz@udp.cl \\ 3 Departamento de Estudios Pedagógicos, Universidad de Chile, Santiago 7800284, Chile; amoncada@uchile.cl \\ 4 Independent Researcher, Santiago 7560969, Chile; mirarrazaval.gh@gmail.com \\ 5 Facultad de Economía y Administración, Pontificia Universidad Católica de Chile, Santiago 7820436, Chile; \\ fjuillerat@uc.cl \\ * Correspondence: vmcabello@uc.cl
}

Citation: Cabello, V.M.; Véliz, K.D.; Moncada-Arce, A.M.; Irarrázaval García-Huidobro, M.; Juillerat, F. Disaster Risk Reduction Education: Tensions and Connections with Sustainable Development Goals. Sustainability 2021, 13, 10933. https://doi.org/10.3390/ su131910933

Academic Editors: Martín Bascopé, Kristina Reiss, Claudia Matus and Amir Khorram-Manesh

Received: 19 July 2021

Accepted: 27 September 2021

Published: 1 October 2021

Publisher's Note: MDPI stays neutral with regard to jurisdictional claims in published maps and institutional affiliations.

Copyright: (c) 2021 by the authors. Licensee MDPI, Basel, Switzerland. This article is an open access article distributed under the terms and conditions of the Creative Commons Attribution (CC BY) license (https:/ / creativecommons.org/licenses/by/ $4.0 /)$.

\begin{abstract}
In the last decades, environmental risks and threats have increased human exposure to natural hazards, often affecting the quality of life, especially for vulnerable groups. This article explores the tensions and connections within educational research concerning disaster risk reduction (DRRE) in relation to Sustainable Development Goals (SDGs). Twenty-seven articles published between 2014 and 2020 in various geographic regions regarding disaster risk reduction (DRR) were reviewed, finding that (a) the participation of children, youth, families, and the community is central; (b) non-formal and informal education are equally as relevant as formal education; (c) DRR initiatives can favor broader objectives, such as reducing poverty or advancing towards sustainable communities; and (d) achieving community resilience in the face of socio-natural disasters requires local voices for the design, implementation, and scaling of strategies. However, certain tensions were also found due to the lack of emphasis on the crucial areas of SDGs, which are related to a comprehensive notion of well-being and health education, including mental health and a gender approach, the limited mitigation of risk aggravating factors arising from extreme poverty and the climate crisis, the disconnection between modern and ancestral knowledge, the "top-down" versus "bottom-up" approach in the generation of local solutions, the role of education on disaster risk reduction as a risk mitigation factor, and the requirements to adjust the curriculum synchronously to global environmental needs, are all discussed, thus highlighting and encouraging the urgent cultural changes needed in the Anthropocene era that can be triggered through disaster risk reduction education.
\end{abstract}

Keywords: disaster risk reduction; education; sustainable development goals

\section{Introduction}

Our changing world has brought periods of conflict due to the enormous challenge of meeting our current human needs without compromising the capacities to meet the needs of future societies. This challenge has increased in the present era of the Anthropocene [1], in which there is evidence of local and global ecological systems with higher levels of vulnerability, economic and social instability/inequity, and fragile political systems. It can be said that we are living in times of ecological precarity [2], where negative encounters between people and the threats of natural disasters are more likely, leading to social, environmental, and economic impacts. However, human efforts are central to transforming this state of vulnerability into a state of security before and after a particular natural phenomenon turns into a disaster [2-4].

The capacity for preparedness, response, and recovery implies that the measure of societal resilience to hazardous conditions varies over space and time and can be 
measured by different index calculations. For example, the social vulnerability index (SoVI) measures the overall social vulnerability based upon socio-economic indicators for different geographic areas. A higher SoVI in a region means that communities need more resources to respond and recover from environmental hazards [5,6]. In addition, the Global Delta Risk Index (GDRI) ranks the spatial single- or multi-hazard vulnerabilities and risks of deltaic social-ecological systems. A higher GDRI in a location means a higher social and environmental vulnerability and risk within that particular delta. Therefore, risk reduction and adaptation strategies are more necessary in such cases [6,7]. Finally, the SC index indicates which factors are dominant in measuring the relative level of social vulnerability based upon socioeconomic and biophysical indicators, which can help allocate disaster risk reduction policies to prevent, mitigate, take actions, and recover from disaster events [8].

In this regard, it is necessary to consider how the interaction of extreme climatic events with inequality and contextual vulnerability affects the well-being of particularly vulnerable groups, such as children and adolescents [9]. Education plays a predominant role in transforming the social space so that the decisions of people, communities, and, on a broad scale, governments minimize social and environmental damage. The Education 2030 agenda, which promotes global agreement regarding the goals that we as humanity must assume for global well-being, suggests critical socio-scientific problems to address educationally, such as sustainable development, disaster risk reduction, and care of the environment [10].

Local environmental risks and threats have increased during the last decades, and extreme climatic events have amplified [11,12], negatively affecting people's lives, especially those in vulnerable groups [13]. For example, the lack of understanding about climate change causes great anxiety in children about their future [14], which could lead to so-called "ecophobia" or permanent fear regarding the uncertainty of their own life on the planet [15]. Some research suggests that anxiety increases as a function of exposure to events. Although it depends on children's ability to understand such impacts and take action, anxiety decreases with community-level social support $[16,17]$.

Due to the above, education has been considered an engine that influences the commitment and direction of student and community action within the world they inhabit. The role of education in this regard aims toward preparing students to respond to uncertainty in ways that are effective, adaptive, and collaborative [18]. The educational curriculum should be understood as a tool under constant reevaluation that allows society to face the future in the best way [19]. The curriculum is understood as a cultural selection of educational purposes, which organizes the trajectory of students over time and which, in the selection of contents, skills, values, or attitudes, is a significant regulator of their future experience [20].

Previous work reported in the educational literature addressing socio-natural disaster risk reduction (DRR) shows that implementing early educational action increases resilience and reduces the vulnerability indexes of students, their families, and communities [21-23]. The participation of children has been considered essential since the beginning of environmental education, where the objective was "to help individuals and social groups develop a sense of responsibility and urgency regarding environmental problems to ensure the appropriate action to resolve those problems" [24], which implies advancing their awareness, knowledge, attitudes, skills, and evaluation capacity. Today, UNICEF has underlined the urgency of addressing children's views in the design and implementation strategies in situations that affect them. From the perspective of children's rights, addressing children's opinions in this way forms an agent of social change. It should be a priority that children express their views and take action locally. This would provide valuable lessons to their communities about addressing socio-natural disasters in a resilient way $[25,26]$.

Socio-natural disaster risk reduction is also related to gender. Due to sociocultural and socioeconomic reasons, the female population is particularly vulnerable to disaster risks [27]. Nonetheless, gender-equal education can improve societies' climate change mitigation, adaptation, and resilience by equipping girls with the competencies to fight 
climate change [28]. Indeed, girls with strong literacy, numeracy, critical thinking, and problem-solving skills help families better process, make decisions, and act on information about risks [29].

Likewise, the ND-GAIN index, which ranks the climate adaptation performance for countries, shows an association between schooling for girls and a country's resilience to climate disasters, increasing for each additional year of girls' education [30]. For instance, countries that have invested in girls' education had fewer losses from droughts and floods than countries with lower levels of girls' education [31]. Prospectively, it is estimated that if $70 \%$ of women aged between 20 and 39 received at least a lower-secondary education, disaster-related deaths in 130 countries in the world could be reduced by $60 \%$ in the following decades [32]. Globally, the gender gap in the dimensions of educational attainment, economic participation and opportunity, health and survival, and political empowerment needs to be reduced substantially [12].

Moreover, education through a gender lens and situated learning need to be understood as a motor change to reduce disaster risks. A comprehensive education might help close this gap, particularly in decision-making for disaster risk reduction. Girls' and women's attainment at all possible education levels based on active, binding participation, female leadership, and decision-making result in pro-environmental and sustainable outcomes for the wider community [33].

Indeed, education attainment increases women's socioeconomic empowerment, economic participation, and opportunities within households. The wider society also gives chances to survive in climate-related extreme weather events relative to men [34].

Situated learning, focused on topics relevant to the community [35], calls for a community approach to promote local resilience to face extreme events [36,37]. Some authors propose that community-based DRR is the most appropriate perspective for building resilient communities [38,39]. This approach involves two requirements: the community and children must be at the center of any strategy to reduce the impacts, and specific actions must be taken to reduce vulnerabilities to disasters [40]. Among these actions, several can be framed in the educational field.

Nonetheless, it seems that education still does not sufficiently consider the relevance of knowledge for action and restitution of rights. To fully understand this shortcoming, we can exemplify the notion of critical scientific literacy. Scientific literacy has been usually understood as the capabilities of people to learn new scientific concepts and acquire skills for further application in their lives or the community living in meaningful contexts [41]. However, critical scientific literacy goes beyond knowledge for and from action [42]. Within this approach, context-based education promotes learning opportunities based on contexts and local needs, pointing to solving global problems and oriented to transform learners' identities, shifting science education towards an integral endeavor with human, social, and political dimensions $[43,44]$. Still, in many cases, educational interventions focus on knowledge of concepts or developing abilities far from a comprehensive community perspective $[2,3]$ or acting with this knowledge to solve local or global problems.

Likewise, the United Nations General Assembly [45], in 2015, presented an agenda for achieving the collective well-being of the population. This agenda introduced 17 Sustainable Development Goals (SDGs) for addressing problems, such as climate change, poverty, and gender inequality. These goals were agreed upon through the largest democratic experiment ever conducted in the global framework with extensive provision for non-state participation [46]. However, some criticism emerged that the SDGs fail to address the complex relationship between the environment and human beings, creating a dichotomy that is insufficient to handle the multiple interconnections between them [47]. It is argued that the SDGs overlook the systemic problem of what is considered development and how it could be achieved [48]. Additionally, this agenda "seems to take for granted some key elements of the current dominant economic agenda, centered on continued growth, trade liberalization, and "partnerships with the private sector" [49], which could be considered impediments to achieving the vision set out by the SDGs. 
Despite the criticism and shortcomings the current development agenda might include, its political relevance is undeniable, shaping global efforts to face the significant challenges ahead. In particular, this agenda invites the political elites to look beyond national interest; human rights are addressed explicitly, and there is a commitment to reducing inequality between the Global North and South and recognizing and dismantling hierarchies within countries themselves [50,51]. Additionally, the SDGs try to apply to all countries, allowing for adaptation within a national/local context.

In the specific context of disaster risk reduction (DRR), there are previous reviews of resilience and development [52] and education or curriculum [18]. However, the intersection between both in childhood education constitutes an under-researched area.

Considering that environmental risks and threats have increased human exposure to natural hazards, it is worth exploring how the DRR focused on education might relate to the SDGs, especially involving children's perspectives and their possibility toward engineering changes at global and local levels. With this purpose, we analyzed the following natural hazardous events: tsunamis, landslides, flooding, variability of weather patterns, wildfires, earthquakes, and volcanic eruptions [53].

The current study reviews educational articles published between 2014 and 2020 addressing disaster risk reduction (DRR), with the intent to answer the following question:

To what extent can research evidence on disaster risk reduction education (DRRE) in childhood be linked to Sustainable Development Goals (SDGs)?

This review aims to explore the tensions and connections found between DRRE initiatives and SDGs in the current Anthropocene era.

\section{Methodology: Review of Studies}

A systematic review of previous works was used to characterize the state of the field, following the steps recommended by Cook and West (2012) [54]. These steps are (1). To define the question that will guide the review (stated in the previous paragraph). (2). To identify the information sources, we decided to use the Web of Science database (core collection) and Scopus, as they contain a vast collection of educational studies. (3). To search for studies that are eligible based on search keywords, we used ("Education"), ("Disaster"), ("Childhood" or "Early Childhood"), and ("Disaster Risk Reduction") with minimal variations depending on the search options of each database. (4). To define inclusion criteria, empirical articles in the English language were included. (5). To define exclusion criteria, articles about pre-service or in-service teachers without connection to childhood or children's community, articles that do not focus on children's education in DRR, literature review studies, or meta-analysis were excluded. (6). To define data abstraction elements, we removed duplicate articles according to their title. (7). To analyze and synthesize the information, two independent researchers who synthesized the information read each article in detail. All the team members agreed on the categorization of the connection between the purpose of DRR education and certain SDGs.

We retrieved 104 articles, 47 from Scopus and 57 from the Web of Science database, following these steps. We removed the repeated articles, which were 25 . The detailed reading process led us to exclude the articles without empirical approaches to education about DRR with the target group, children. Finally, 27 articles were selected for this review, as shown in Figure 1. The list of the articles included are presented in the Results section as a table, also linked to Figure 1. 


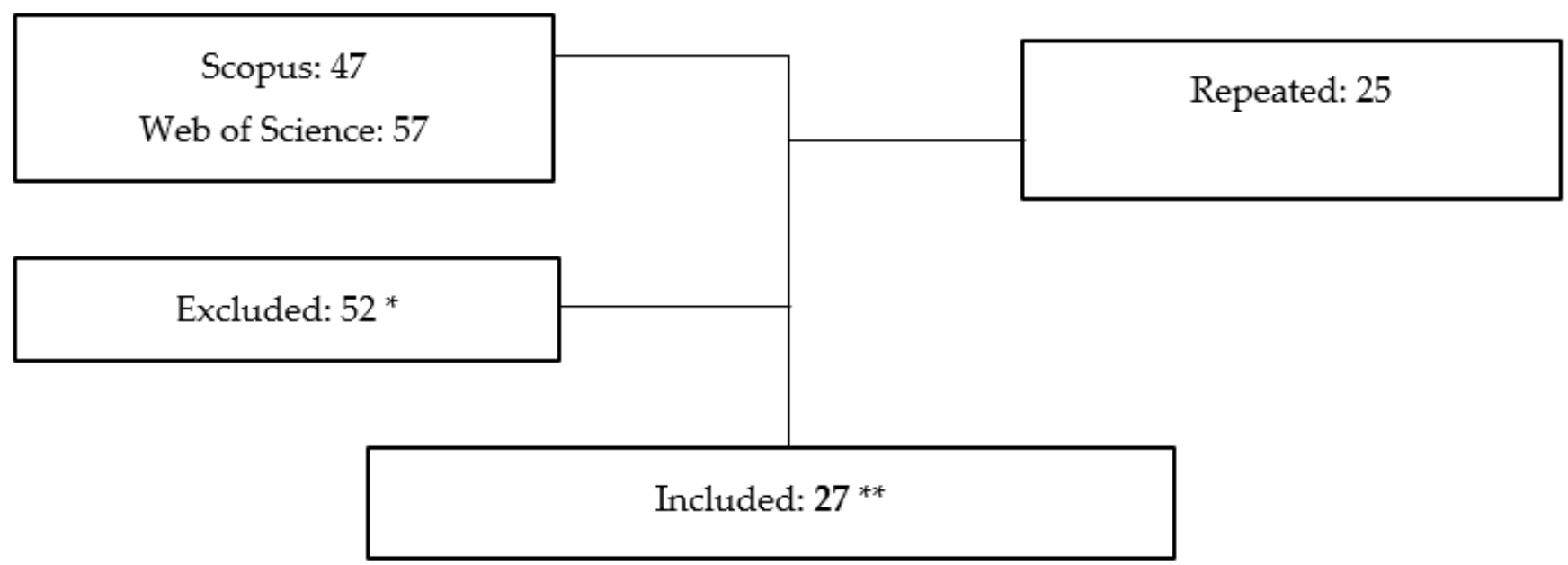

Figure 1. Flow diagram of steps in the articles' review process ( ${ }^{*}$ Exclusion criteria: articles about pre-service or in-service teachers without connection to childhood or children's community, articles that do not focus on children's education in DRR, literature review studies, or meta-analysis. ${ }^{* *}$ These are detailed in Table 1).

Table 1. List of articles included in the present review.

\begin{tabular}{|c|c|c|c|c|c|c|c|c|}
\hline \multirow[t]{2}{*}{ Title } & \multirow[t]{2}{*}{ Authors } & \multirow[t]{2}{*}{ Year } & \multirow[t]{2}{*}{ Area } & \multicolumn{5}{|c|}{ SDGs } \\
\hline & & & & 1 & 3 & 4 & 11 & 13 \\
\hline $\begin{array}{c}\text { A1. Fostering student participation in } \\
\text { disaster risk reduction through disaster } \\
\text { video games }\end{array}$ & Gampell et al. & 2020 & $\begin{array}{l}\text { New } \\
\text { Zealand }\end{array}$ & & & $X$ & & \\
\hline $\begin{array}{l}\text { A2. Kura e Tai Āniwhaniwha (schools and } \\
\text { tsunami): bi-cultural and student-centered } \\
\text { tsunami education in Aotearoa New Zealand }\end{array}$ & Kaiser, L.; Boersen, K. & 2020 & $\begin{array}{l}\text { New } \\
\text { Zealand }\end{array}$ & & & $x$ & $x$ & \\
\hline $\begin{array}{l}\text { A3. From tale to reality: Geographical } \\
\text { differences in children's } \\
\text { flood-risk perception }\end{array}$ & $\begin{array}{l}\text { Carone, M.T.; } \\
\text { Marincioni, F. }\end{array}$ & 2020 & Italy & & $X$ & $X$ & & \\
\hline $\begin{array}{l}\text { A4. Participatory approach to natural hazard } \\
\text { education for hydrological risk reduction }\end{array}$ & $\begin{array}{l}\text { Piangiamore, G.L.; } \\
\text { Musacchio, G }\end{array}$ & 2017 & Italy & & & $X$ & $x$ & \\
\hline $\begin{array}{l}\text { A5. Disaster risk reduction education in } \\
\text { Indonesia: Challenges and recommendations } \\
\text { for scaling up }\end{array}$ & Amri et al. & 2017 & Indonesia & & & $X$ & & \\
\hline $\begin{array}{l}\text { A6. Informal education for disaster } \\
\text { risk reduction }\end{array}$ & Bernhardsdottir et al. & 2016 & Europe & & & $x$ & $x$ & \\
\hline $\begin{array}{l}\text { A7. Education: Can a bottom-up strategy } \\
\text { help for earthquake disaster prevention? }\end{array}$ & Musacchio et al. & 2016 & Europe & & & $X$ & $x$ & \\
\hline $\begin{array}{l}\text { A8. Natural hazards revealed to children: } \\
\text { The other side of prevention }\end{array}$ & Piangiamore et al. & 2015 & Europe & & & $X$ & $x$ & \\
\hline $\begin{array}{c}\text { A9. CDMG: Crises and disasters } \\
\text { management game (video game to teach } \\
\text { Arab children how to handle emergencies } \\
\text { and crises) }\end{array}$ & Shohieb, S. & 2018 & Egypt & & & $x$ & & \\
\hline $\begin{array}{l}\text { A10. Transversal integration of } \\
\text { geohydrological risks in an elementary } \\
\text { school in Brazil: A disaster } \\
\text { education experiment }\end{array}$ & De Mendonca et al. & 2019 & Brazil & & & $x$ & $x$ & $\mathrm{X}$ \\
\hline $\begin{array}{c}\text { A11. Understanding operations of floating } \\
\text { schools: A case of Shidhulai Swanirvar } \\
\text { Sangstha in Bangladesh }\end{array}$ & Ahmed et al. & 2016 & Bangladesh & $x$ & & $x$ & $x$ & $\mathrm{X}$ \\
\hline
\end{tabular}


Table 1. Cont.

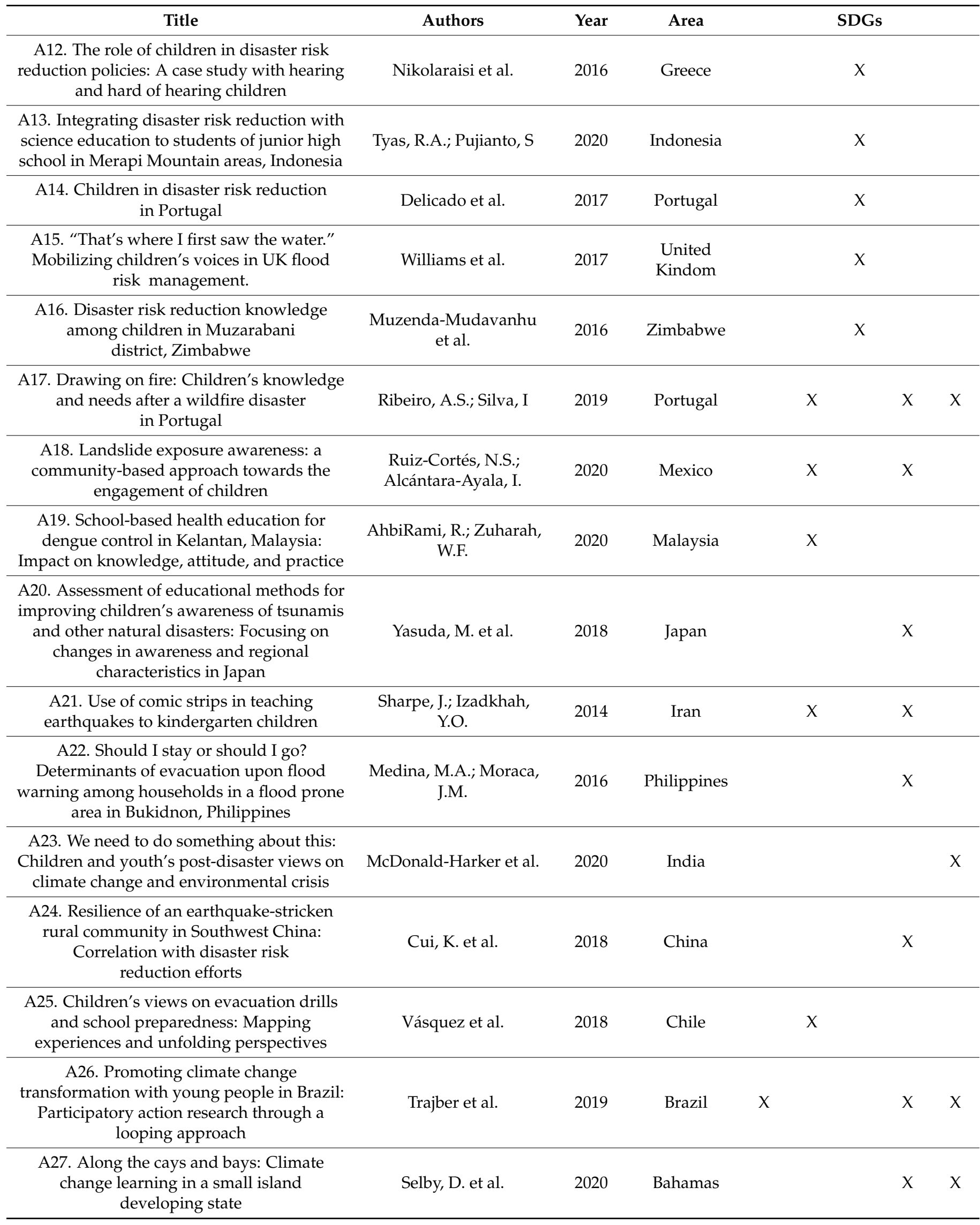


The comparison of the primary purposes of each study and the links with SDGs allow us to find emergent connections with this agenda and identify some conceptual tensions and research gaps for future studies.

Most of the studies were carried out in Europe and Asia and only occasionally in the Americas, covering diverse types of hazards. Figures S1 and S2 show the details.

The specific analysis of the selected articles followed an interpretative paradigm, looking for comprehension and relevance to understand the topic. The objective of our study was not to inform practice but to scope the current trends in the studies about DRRE, their connections with SDGs, and the areas in which more research is needed. Therefore, the steps we followed were consistent with an interpretive approach to qualitative evidence synthesis. We analyzed the selected articles in the forward and backward directions and used a thematic synthesis, as we explain below.

Forward direction. First, the 27 articles were analyzed and organized in a summary sheet to identify the central theme and the extent to which each one was connected to SDGs. The direction of the analysis went from the articles to the SDGs. Although there are different emphases in the definitions of these goals among organizations, we used UNESCO's definition-presented below-of SDGs, which explicitly links several of the SDGs with educational strategies [55].

We created a double-entry grid to systematize the information of the articles' authors, year, summary, aim, country, type of disaster, and what the SDGs were orientated towards. In a blind process, two independent researchers categorized the SDGs involved in each of the articles. If there were inter-coder disagreements, they were reviewed in an argumentative discussion until 100\% consensus was reached. This analysis found that some articles could be linked to more than one SDG, as shown in Figure 2a. Once the first matrix was completed, the team's five members participated in iterative discussion sessions to determine the final connections between the studies' purposes and the SDGs. The SDGs that matched to at least one article were five:

SDG 1: Eradicate poverty by developing human capacity and productivity through quality education and skills development; science, technology, and innovation; access to ICTs and the media; sustainable management of terrestrial and marine resources; protection and promotion of cultural heritage and of the diversity of cultural expressions.

SDG 3: Access to safe, inclusive, and health-promoting learning environments and comprehensive sexuality education.

SDG 4: Development of education systems which foster quality inclusive education and promote lifelong learning opportunities for all.

SDG 11: Promote inclusive sustainable cities through quality education for all, safeguarding cultural heritage, innovation, and creativity, promoting environmental sustainability, and building resilience to the effects of climate change, disasters, and conflicts.

SDG 13: Provide climate services in support of climate change mitigation and adaptation efforts with a focus on knowledge (co)production and dissemination, policy advice, education, public awareness, and capacity development.

Backward direction. Second, to identify the coverage of the SDGs by the articles found, we connected the selected papers to the SDGs by generating a critical interpretive synthesis of each SDG regarding the articles' purposes. In an independent critical appraisal, we scrutinized the main targets presented in each SGD and examined whether they were addressed entirely or partially by the group of articles we had found a match with. This analysis process was done from the SDGs to the scope of the articles, looking at the degree of qualitative saturation of the SDG goal definition by the articles found in DRRE, as shown in Figure 2b. 


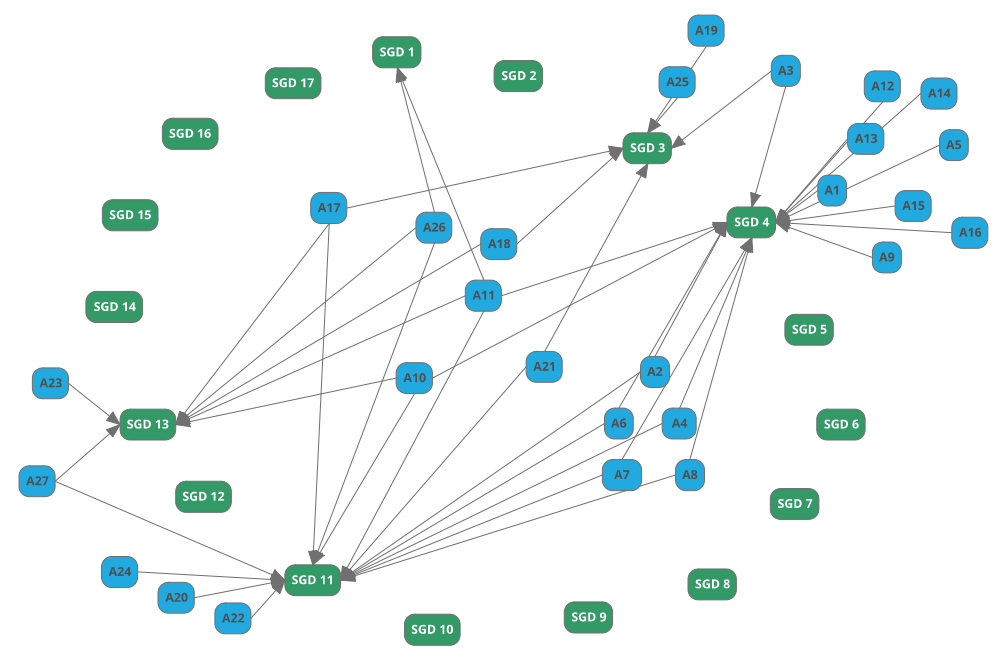

(a)

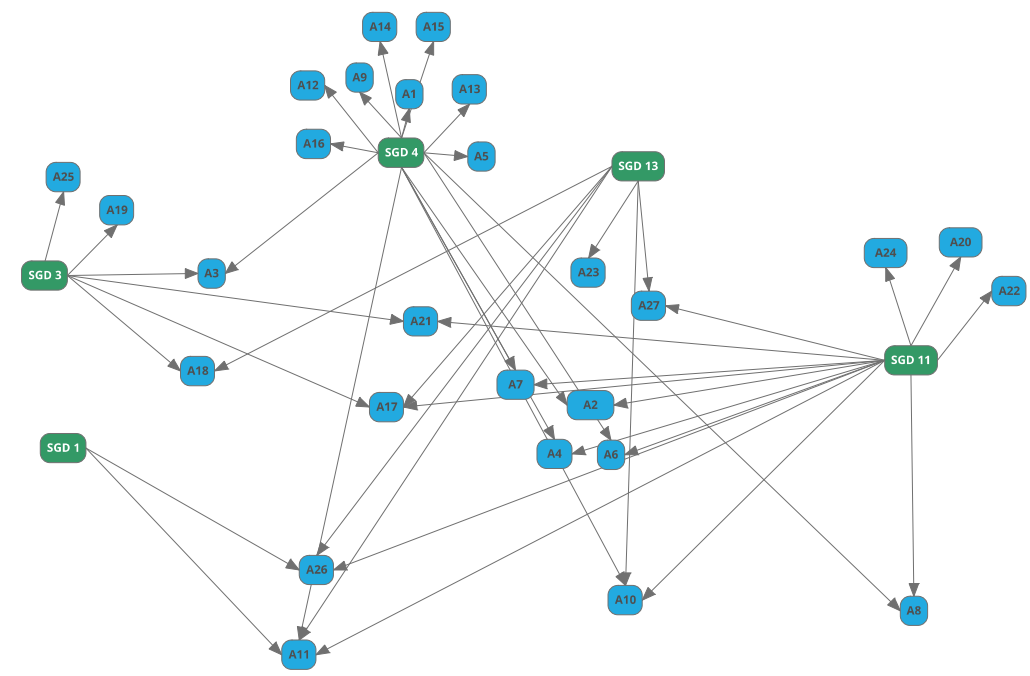

(b)

Figure 2. Influence graphs. (a) Forward direction: from articles to SDGs. (b) Backward direction: from SDGs to articles.

An illustrative example of these forward direction and backward direction analysis steps is the following:

Forward direction: we found that six articles were connected to SDG 3.

Backward direction: considering the definition of SDG 3 (access to safe, inclusive, and health-promoting learning environments and comprehensive sexuality education), we appraised the main themes of the definition, in this case: (1) access to safe learning environments, (2) access to inclusive learning environments, (3) access to health-promoting learning environments, and (4) comprehensive sexuality education. Later, we matched the selected articles' scope with those themes, finding that theme four was not referred to by any article. Thus, we recognized this lack of coverage as an emerging tension regarding DRRE in connection with SDGs.

Thematic Synthesis. Third, after the process illustrated in the previous diagrams, we used thematic synthesis, focusing on re-interpretation for drawing conclusions based on common elements across the heterogeneous studies we had found to understand how the main aspects connect and interact. We represented the findings in geography and network maps and their aggregation into the SDGs' definition framework categories. We signaled 
the connections and tensions we found in the articles regarding DRRE and the SDGs in these categories, described in the next section.

\section{Results}

Of the 27 articles that met the inclusion criteria, two connected with SDG 1, six with SDG 3, 16 with SDG 4, 14 with SDG 11, and six with SDG 13. Some articles were linked with more than one SDG, as detailed in the following pages and Table 1.

Americas, covering diverse types of hazards. Figures S1 and S2 show the details.

Concerning SDG 1, which aims to end poverty around the world through multidimensional approaches, three articles were related to aspects of education and access to information. In Trajber et al. (2019) [56], the authors analyzed the eradication of poverty and positive climate transformation by young people in Brazil through citizen participation and empowerment, political action, and the co-production of DRR actions regarding real problems. The involvement of young people in participatory action research revealed their transformation into active agents of change. It decreased the socioeconomic effects derived from systematic exposure to socio-environmental disasters in vulnerable localities. Additionally, to alleviate poverty through education, Ahmed et al. (2016) [57] analyzed the implementation of floating schools in Bangladesh in a socioeconomically vulnerable population. This measure, supported by non-governmental organizations (NGOs), improved school attendance and decreased the dropout rate of young people, particularly girls, after floods. Finally, Muzenda-Mudavanhu et al. (2016) explored to what extent DRRE programs influenced children's risk perception in Muzarabani. This study connected worries with risk perception and preparedness; however, children's awareness of risk does not mean that they were prepared and actively involved in risk reduction. The critical point is children's' coping capacity, composed of the availability of resources, political commitment, and social support of support preparedness.

Studies related to SDG 3, aimed at accessing learning environments that promote health and sex education, were carried out in Malaysia, Iran, Italy, Portugal, Mexico, and Chile. These studies aimed to protect people and promote their well-being and physical health in the context of disasters or risks. However, no interventions included sex education.

Most of the studies related to this SDG 3 sought to prevent disasters but can also be differentiated according to their temporality. Before disasters occur, AhbiRami and Zuharah (2020) [58] proposed focusing health education programs on children from communities in which their risk perception is low and prioritize interventions in communities where disaster risk is indeed high, intending to achieve knowledge, attitude, and awareness practices that allow the construction of resilience. Resilience can be fostered by working with whole communities, including children. For example, it is possible to use workshops that, aided by technology such as drones, increase local concern about aspects of construction that affect school safety and well-being in risk areas [59] and favor the joint development of evacuation plans, redefining safe places from a multidimensional perspective [60]. During a disaster, decision-makers must consider the needs of children concerning the different geographic conditions in which they live [61]. Post-disaster, it is suggested that education regarding self-protective measures be reinforced. These education programs should be appropriate for children and include parents since infants imitate their behaviors, thus promoting the resilience of the entire community [62].

These studies suggest using tools that, from the education approach in health and self-protection, allowed communities to face risks and prevent such hazards from turning into disasters or rework their experiences once they had occurred. Some of these tools are drawings and children's stories [62], comics or fictional stories [61,63], in-depth interviews and focus groups to determine the level of preparedness and risk perception [60], and also group discussions for community training purposes [59].

Concerning SDG 4, which aims to achieve quality education, 11 studies can be linked. These studies were carried out in Italy, Iceland, Portugal, Egypt, Indonesia, the United 
Kingdom, Brazil, Greece, Zimbabwe, and New Zealand and considered natural hazards, such as earthquakes, tsunamis, floods, fires, landslides, and volcanic eruptions. All the articles focused on DRRE, except one [57], which focused on access to education.

Although most of the studies were focused on formal education systems, half of these also included non-formal education, highlighting the idea that educational interventions should target school children and their families and the community [64]. Most studies also agreed on the importance of including the knowledge of local communities in the design and implementation of initiatives $[57,61,64]$. Some studies emphasized the relevance of designing initiatives from the "bottom-up" (that is, from teachers, students, or communities to the local authorities) since it considers specific regional needs in the design of the plans $[65,66]$, fosters awareness of the social dimension of disasters [67], and promotes the participation of children and adults in the proposed activities [26,61,66,68-73].

On the other hand, the participation of experts in the design and execution of activities is also key to their success [64]. In the evaluation of the programs, there is no academic consensus on which indicators are credible evidence of the effectiveness of DRR programs in terms of children learning and changing their behaviors [70].

The strategies used in the studies categorized in SDG 4 included the use of video games, stories, and interviews since they promote learning of DRR and encourage student participation because it requires the genuine involvement of students and teachers working together to find ways to reduce the gaps between DRR policy and practice $[65,66]$. Kaiser and Boersen (2020) [71] proposed methodologies to include local voices and the traditional knowledge of the native community and ancestral peoples in the creation of relevant and pertinent material in the preparation and confrontation of a disaster (e.g., tsunamis). Likewise, Carone and Marincioni (2019) [61] and Williams et al. (2017) [73] emphasized the role that children and young people play in designing and implementing DRRE activities aimed at managing situations in their particular context.

The integration of disaster risk reduction efforts with natural science learning tools can effectively increase students' preparedness in facing disasters. Learning tools developed for students might include syllabus, lesson plans, student worksheets, and handouts [74]. In addition, the design of inclusive tools for disaster education programs focused on children and young people with disabilities needs to be worked with a differentiated instruction strategy so that their perceptions and knowledge regarding disasters and their role to build resilience is proper for their reality [75].

In terms of results, Ahmed et al. (2016) [57] facilitated access to education designed for a community affected by floods, demonstrating a positive social, economic, and environmental impact. Bernhardsdottir et al. (2016) [69] compared the degree of involvement of local authorities in DRR with how information was shared with schools that already had emergency plans for earthquakes. However, the DRRE was not suitable in risky areas. It was concluded that local authorities, school administrations, and health institutions could be risk reduction agents if they improved the communication of information. For example, they could provide information about risk prevention through disaster drill maps or by emphasizing the need for post-disaster equipment. Likewise, the lack of DRR in the school curriculum makes children vulnerable due to their age [76].

Finally, it is essential to evaluate the successful initiatives, expand them to other communities, especially vulnerable communities, and provide public policy recommendations from the local level $[26,67,68,73,76]$.

Our review linked 14 articles to SDG 11, which aimed to promote sustainable cities through quality education for all. The studies were carried out in the Bahamas, Mexico, Brazil, Egypt, Bangladesh, Iran, China, the Philippines, India, Japan, Italy, Portugal, Iceland, and Oceania.

Six of the works associated with this SDG contributed to our knowledge of DRR. Two of them investigated the experiences and imaginations of preschool children; the first analyzed children's capacities and resilience during disaster situations [63], and the second, the experiences of children in wildfires [62]. Both studies are exploratory and 
call for future studies that lead to a deeper understanding of DRR in children. Other studies explored the following subjects: the factors that influence evacuation decisions after receiving notice from the authorities [77]; how local authorities transmit information about risks to schools [69]; differences in response to DRR activities according to geographic regions in Japan [78], and if the proposed activities improved school children's awareness of disaster prevention [79].

Most of the research focused on developing sustainable communities and contributing to the development of skills associated with resilience from a social perspective, such as promoting the development of empathy, self-care, and caring for others [64,67], both within the educational system and outside of it $[57,80]$. In general, the articles valued local knowledge and promoted community participation to find possible solutions to community problems $[63,71,80]$, and gave high value to interdisciplinary work [70]. Trajber et al. (2019) [56] presented a methodology that would allow young people and other protagonists to organize and act in the face of complex and multiscale processes. Similarly, Ruiz-Cortés and Alcántara-Ayala (2020) [59] and Delicado et al., (2017) [26] emphasized the need for the permanent participation of children in DRR and the use of a community-based approach to educating future decision-makers. For their part, Selby et al. (2020) [80] proposed redefining "good practices" in climate change education, for example, fusing formal and non-formal education.

Concerning SDG 13, which seeks to combat climate change and its impacts by implementing actions in multiple sectors, six studies addressed this objective from adaptation through education and the establishment of cooperation between countries and communities. Mitchell and Borchard (2014) [22] showed that boys and girls could develop innovative and low-cost solutions to real-world challenges, understand complex concepts, and develop actions to reduce risks. On the other hand, NGOs' construction of public infrastructure is a symbol of climate action using sustainable and low-cost materials native to the area [57].

Consequently, it is evident that previous experiences with natural hazards resulting from climate change increase the involvement of young people since they have the desire to reverse or at least limit their consequences to avoid future socio-environmental disasters [62,70,81]. Additionally, giving school children and young people the responsibility of finding solutions to local problems fosters their awareness. It may encourage them to take the actual initiative to help reverse socio-environmental damage in the future [55]. We conclude from the analysis of these articles that participation in DRR initiatives allows children and young people to become active agents with the capacity to persuade, convince, and influence adults.

\section{Discussion}

The present work explored to what extent the research evidence on disaster risk reduction education (DRRE) can be linked to sustainable development goals (SDGs) in the current Anthropocene era. Empirical articles were selected and categorized by their possible link with an SDG. Some studies were related to more than one SDG, which accounted for the multidimensional nature of both disasters and DRRE breadths.

Initiatives in DRRE that included children generally reported positive results $[22,56,58-64,67,72,74,75,80]$. Previous research shows an increase in children's awareness about disasters, which encourages them to take initiatives to reverse socioenvironmental damage. The same occurred in settings that value the role of adolescents and young people $[56,61,62,65,66,68-72,81]$, who can become active agents in their communities and influence other members. In some studies, the role of NGOs in generating educational support is highlighted [65,80], as well as the relevance of incorporating local authorities [69] and stakeholders into the strategies [61], as both of these measures can allow for recommendations to become public policy at the local level $[67,68]$.

The articles generally valued local knowledge and community participation in DRR $[56,63,71,80]$. However, we wonder about the extent to which the involvement of the communities, especially children, has been consultative or if the stakeholders gave real 
opportunities to the community to make decisions. This leads to a re-signification of the desirable practices in formal, informal, and non-formal education towards developing formative actions that arise from the communities themselves [80], with local and cultural relevance [71]. This emphasis coincides with what some authors theoretically proposed, such as that community-based DRR is the most appropriate perspective to shape resilient communities $[38,39]$ and the centrality of children in any strategy to reduce impacts and vulnerabilities to disasters through educational actions [40].

Even though this review focused on searching for evidence with keywords from the educational area, several articles were linked to SDGs related to poverty reduction, health, and sustainable communities. This finding is valuable because it leads us to understand that the educational changes necessary in these current times highlight the role of traditional formal education and suggest expanding its scope. Education has local relevance and is capable of mobilizing actions to restore people's well-being. Therefore, education should be oriented toward particular locations or the needs of the territories and consider the local risks, threats, and contextual capacities, and children in the community as agents of change. Here, we reflect upon the complexity of DRR processes, considering that risk consists of both vulnerability and exposure to natural hazards [82]. We strongly believe that DRRE plays a crucial role in risk mitigation by reducing peoples' vulnerability.

Beyond the previously mentioned consensus, we can interpret tensions in the educational approach to DRR due to its partial relationship with SDGs, which allows us to rethink the notion of quality education in the current times. In this context, we take the position that the DRRE must be contextualized, territorially relevant, inclusive of various educational agents, incorporate local and native voices, and allow local actions to be scaled towards broader social welfare policies. This vision comes from four findings of this research review.

First, we noticed areas of SDGs that have not received attention. For example, although evidence supports the idea that exposure to socio-natural disasters affects children's emotional regulation, cognition, and academic performance [83,84], no studies comprehensively address children's physical and mental health. Likewise, our review did not show studies including a gender perspective, even though women are much more vulnerable than men post-disaster and more likely to be marginalized and their needs neglected [27,85]. Only one of the studies reported better results in girls' school attendance related to DRRE [56]; however, this was not intentional in the study but rather a serendipitous result. We consider that reducing gender inequalities is relevant not only because it is one of the SDGs but because gender appears to affect children's safety, recovery, and other outcomes, such as continued education [85]. Similarly, gender-equal education aids countries in adapting to and mitigating the climate crisis while also diminishing the rate of impact of global warming [71,78], which supports the inclusion of this crucial variable in DRRE from early childhood education $[22,86]$.

Second, several articles recognize poverty and climate change as factors that aggravate the risks of socio-natural disasters [22,59,77]; however, these studies do not necessarily point to concrete children's behaviors for reversing the origins of these aggravating factors. Long-term learning throughout the community allows a reduction of socio-economic gaps by improving human capacities and resilience. However, it must be said that building resilience alone cannot directly reduce poverty due to its multidimensionality [52].

Third, the locations of the DRRE studies were diverse, as were the disasters they sought to mitigate and the strategies they used. However, the knowledge of indigenous people and local or ancestral knowledge is rarely considered when facing or preventing crises, which calls for a discussion about the hegemony of certain types of knowledge and actors to face DRR. This also makes us question who the DRRE is focused on, who executes it, who receives it, and the range of decisions in which educational agentsstudents, teachers, administrators, families, and neighbors-are incorporated. This tension becomes evident when noting that while many studies declare it urgent that the DRRE allow greater children's participation in local planning, few give an actual ability to impact 
specific products, such as mitigation or evacuation plans [60]. This reinforces the tension between "top-down" and "bottom-up" solutions and the tendency to understand children's participation as mere implementers of adults' instructions. Let us remember that scientific literacy, a global goal of scientific education, means developing the capability of citizen participation to give the tools for actual citizen participation. Children need to have a real space of influence within the decisions in the programs of the DRRE.

Fourth, some articles analyzed the family as a particular unit in constructing children's resilience $[78,79]$. Cooperation and communication are essential to design ex-ante preparedness plans for socio-natural disasters and ex-post measures that will help their reunification $[70,77]$ in the framework of rights. Children have the right to live in a family that cares for their well-being [22]; however, not all families can exercise this right in the same way. For example, it is known that timely decision-making during an evacuation in the face of a disaster is correlated with family educational level and purchasing power [77].

It is worth noticing that some models might help us explore the incorporation of local communities in social welfare policies to a greater degree than hitherto. For example, the Penta-Helix model [87-90] allows for exploring the relationships between different stakeholders at diverse levels, such as government, business, academia, media, and society [90]. Thus, this model might enable local communities to have a broader capacity for genuine cooperation and more significant work synergies in the ecosystem for social welfare policies. Therefore, future research on DRRE might benefit from including these models for understanding obstacles and enablers between SDGs agenda and DRRE.

Finally, participation has been one of the objectives of environmental education since its inception [24], so it is not surprising that the DRRE initiatives found in this review tend to have emphasized this point through participatory methodologies and community involvement in addressing local problems. Indeed, under this idea, DRRE plans were beneficial for community resilience building through participatory initiatives that identify hazards to design and implement protection and recovery strategies [47]. However, in the present work, we find DRRE activities from formal education appear to have a limited reach in both the problems they address and their effect on the communities outside schools. Moreover, informal education has exhibited creative and transformative methods of dealing with local issues and is as important as formal education in its approach [69]. Although informal education could be considered less important than formal education for some, in this article, we want to emphasize the relevance of non-formal initiatives to involve the community in DRRE actions. Consequently, we reflect on the need to merge these types of education to achieve a transformative DRRE for individual and collective capacities and as an engine for society's local and epistemic cultural development (i.e., towards non-academic perspectives or reducing adultism centrism in decision-making). This would compel the required changes of the formal education curriculum to adjust to global environmental needs synchronously and encourage the urgent cultural changes needed in the Anthropocene era.

In closing, a significant challenge that we can observe in DRRE is related to the effectiveness of the programs studied. Specifically, the lack of agreement regarding what counts as evidence in evaluating efficacy is problematic [70], which leads us to note the need to investigate territorially relevant indicators in DRRE. For example, if we consider that the formation of sustainable communities necessarily implies a change in how these communities are inhabited, the knowledge generated should influence urban public policy [86]. Thus, new research ideas emerge on how the knowledge generated about DRR is communicated to the different actors (local and governmental) and how DRRE programs can be evaluated over time. In the same way, considering the scarcity of educational initiatives reported that focus on understanding children's ideas about the causes or origins of socio-natural disasters, various local voices should be heard at an international level to raise awareness and thus stop the advance of the climate emergency. Given this, we recommend that future evaluations assess the conditions and responsibilities of DRRE and 
view the communities as active agents, including all their members, especially those who have been historically excluded, such as children and women, among others.

Without a doubt, this review has certain limitations that should be noted. The central limit is that the search was exclusively carried out in mainstream educational databases, which bias the English language, possibly reducing the chances of accessing experiences from linguistically diverse countries. Although a wide range of geographic contexts was covered, it is necessary to explore other sources of analysis or knowledge dissemination beyond academic articles, which may not recognize this type of progress at the community level. In the same way, we focused the review towards DRRE in childhood, leaving out studies solely from teachers' perspectives. However, it is crucial to expand the field of possible alternatives in making decisions about DRRE, for example, moving towards changes or curricular decisions that are influenced by teachers and include children as curriculum builders, recalling that the curriculum is a cultural selection for educational purposes that regulate students' school experience [20].

Moreover, to address these concerns, education policymakers must supplement traditional climate education with a bolder curriculum, helping students make a personal connection to socio-scientific issues, such as the climate crisis, interrogate its sources, and adopt new ways of thinking about and being on the planet [91]. Likewise, climate education should also provide students with opportunities to put values, such as equality, care, stewardship, and collaboration, into action [92].

Taking this point further, and based on this literature review, we invite readers to problematize the existing relationship between formal education and all those types of education outside of this scope. We have found authors that call for reshaping the boundaries between formal and non-formal education. We have reviewed initiatives that arise from NGOs or civil organizations that have tackled specific problems with a deeper understanding of the local problems. This kind of approach to DRRE considers the local knowledge and resources that communities possess to (co)construct solutions that engage the whole community in the social and political dimensions. Thus, the need for creative solutions, generating communal engagement and commitment, and re-signifying the educational practices within these specific communities are paramount for making a more sustainable and equitable future.

Supplementary Materials: The following are available online at https:/ /www.mdpi.com/article/10 .3390/su131910933/s1, Figure S1: Map with types of hazards covered in the studies, Figure S2: Map with the number of articles about disaster risk reduction education connected to SDGs.

Author Contributions: Conceptualization, V.M.C. and K.D.V.; methodology, V.M.C., K.D.V. and A.M.M.-A.; software, M.I.G.-H.; validation, V.M.C., K.D.V. and A.M.M.-A.; formal analysis, M.I.G.-H. and F.J.; investigation, M.I.G.-H. and F.J.; resources, V.M.C. and K.D.V.; data curation, V.M.C., K.D.V. and A.M.M.-A.; writing—original draft preparation, V.M.C., K.D.V. and A.M.M.-A.; writing-review and editing, M.I.G.-H.; visualization, K.D.V.; supervision, V.M.C. and K.D.V.; project administration, V.M.C. and K.D.V.; funding acquisition, V.M.C. All authors have read and agreed to the published version of the manuscript.

Funding: This research was funded by Research Center for Integrated Disaster Risk Management (CIGIDEN), ANID/FONDAP/15110017, and ANID/FONDECYT/11181050.

Acknowledgments: Rodrigo Ramírez director of Guemil Icons for Emergency (accessed on 16 August 2021), Fondart Nacional/Diseño/Investigación, folio 545568, used in the map's visualization of hazards.

Conflicts of Interest: The authors declare no conflict of interest. The funders had no role in the design of the study, in the collection, analyses, or interpretation of data, in the writing of the manuscript, or in the decision to publish the results. 


\section{References}

1. Creutzig, F. Limits to liberalism: Considerations for the anthropocene. Ecol. Econ. 2020, 177, 106763. [CrossRef]

2. Neimark, B.; Mahanty, S.; Dressler, W.; Hicks, C. Not just participation: The rise of the eco-precariat in the green economy. Antipode 2020, 52, 496-521. [CrossRef] [PubMed]

3. Li, H. Rethinking vulnerability in the age of anthropocene: Toward ecologizing education. Educ. Theory 2017, 67, 435-451. [CrossRef]

4. Souza, D.T.; Jacobi, P.R.; Wals, A.E. Overcoming socio-ecological vulnerability through community-based social learning: The case of Lomba do Pinheiro in Porto Alegre, Brazil. Local Environ. 2020, 25, 179-201. [CrossRef]

5. Cutter, S.; Boruff, B.; Shirley, W. Social vulnerability to environmental hazards. Soc. Sci. Q. 2003, 84, 242-261. [CrossRef]

6. Anderson, C.C.; Hagenlocher, M.; Renaud, F.G.; Sebesvari, Z.; Cutter, S.L.; Emrich, C.T. Comparing index-based vulnerability assessments in the Mississippi Delta: Implications of contrasting theories, indicators, and aggregation methodologies. Int. J. Disaster Risk Reduct. 2019, 39, 101128. [CrossRef]

7. Hagenlocher, M.; Renaud, F.G.; Haas, S.; Sebesvari, Z. Vulnerability and risk of deltaic social-ecological systems exposed to multiple hazards. Sci. Total Environ. 2018, 631, 71-80. [CrossRef]

8. Nasution, B.I.; Kurniawan, R.; Siagian, T.H.; Fudholi, A. Revisiting social vulnerability analysis in Indonesia: An optimized spatial fuzzy clustering approach. Int. J. Disaster Risk Reduct. 2020, 51, 101801. [CrossRef]

9. Garcia, D.M.; Sheehan, M.C. Extreme weather-driven disasters and children's health. Int. J. Health Serv. 2016, 46, 79-105. [CrossRef] [PubMed]

10. UNESCO. Educación 2030: Declaración de Incheon y Marco de Acción para la Realización del Objetivo de Desarrollo Sostenible 4; UNESCO: Paris, France, 2015.

11. Watts, N.; Adger, W.N.; Ayeb-Karlsson, S.; Bai, Y.; Byass, P.; Campbell-Lendrum, D.; Coulbourn, T.; Cox, P.; Davies, M.; Depledge, P.; et al. The Lancet Countdown: Tracking progress on health and climate change. Lancet 2017, 389, 1151-1164. [CrossRef]

12. Levy, B.S.; Patz, J.A. Climate change, human rights, and social justice. Ann. Glob. Health 2015, 81, 310-322. [CrossRef]

13. Simpson, D.M.; Weissbecker, I.; Sephton, S.E. Extreme weather-related events: Implications for mental health and well-being. In Climate Change and Human Well-Being. International and Cultural Psychology; Weissbecker, I., Ed.; Springer: New York, NY, USA, 2011; pp. 57-78.

14. Majeed, H.; Lee, J. The impact of climate change on youth depression and mental health. Lancet Planet Health 2017, 1, 94-95. [CrossRef]

15. Strife, S.J. Children's environmental concerns: Expressing ecophobia. J. Environ. Educ. 2012, 43, 37-54. [CrossRef]

16. Kousky, C. Impacts of natural disasters on children. Future Child. 2016, 26, 73-92. [CrossRef]

17. Lai, B.S.; Esnard, A.; Lowe, S.R.; Peek, L. Schools and disasters: Safety and mental health assessment and interventions for children. Curr. Psychiatry Rep. 2016, 18, 109. [CrossRef]

18. Gough, S.; Stables, A. Interpretation as adaptation: Education for survival in uncertain times. Curric. Inq. 2012, 42, 368-385. [CrossRef]

19. Gough, S. Co-evolution, knowledge and education: Adding value to learners' options. Stud. Philos. Educ. 2008, 28, 27-38. [CrossRef]

20. Cox, C. El currículum escolar del futuro. Rev. Perspect. 2001, 4, 213-232.

21. Meyer, M.; Hendricks, M.; Newman, G.; Horney, J.; Berke, P.; Masterson, J.; Sansom, G.; Cousins, T.; Van Zandt, S.; Cooper, J. Participatory action research: Tools for disaster resilience education. Int. J. Disaster Resil. Built Environ. 2018, 9, 402-419. [CrossRef] [PubMed]

22. Mitchell, P.; Borchard, C. Mainstreaming children's vulnerabilities and capacities into community-based adaptation to enhance impact. Clim. Dev. 2014, 6, 372-381. [CrossRef]

23. Shaw, R.; Takeuchi, Y.; Rouhban, B. Education, capacity building and public awareness for disaster reduction. In LandslidesDisaster Risk Reduction; Sassa, K., Canuti, P., Eds.; Springer: Berlin, Germany, 2009; pp. 499-515.

24. UNESCO. The Belgrade Charter. A Global Framework for Environmental Education; UNESCO: Paris, France, 1975.

25. Stanberry, L.R.; Thomson, M.C.; James, W. Prioritizing the needs of children in a changing climate. PLoS Med. 2018, 15, e1002627. [CrossRef]

26. Delicado, A.; Rowland, J.; Fonseca, S.; de Almeida, A.N.; Schmidt, L.; Ribeiro, A.S. Children in disaster risk reduction in Portugal: Policies, education, and (non) participation. Int. J. Disaster Risk Sci. 2017, 8, 246-257. [CrossRef]

27. Miranda, D.; Campos, K.; Tironi, M.; Valdivieso, S.; Carraro, V.; Palma, K.; Juzam, L. Gestión del Riesgo de Desastres desde una Perspectiva de Género Interseccional. In Serie Policy Papers CIGIDEN; CIGIDEN: Macul, Chile, 2021; ISBN 978-956-14-2807-2.

28. Fry, L.; Lei, P. A Greener, Fairer Future: Why Leaders Need to Invest in Climate and Girls' Education; Malala Fund: Washington, DC, USA, 2021.

29. Muttarak, R.; Lutz, W. Is Education a Key to Reducing Vulnerability to Natural Disasters and Hence Unavoidable Climate Change? Available online: http:/ /www.alz.org/what-is-dementia.asp (accessed on 16 August 2021).

30. Braga, A.; Kwauk, C. 3 Ways to Link Girls' Education Actors to Climate Actions; Brookings Institution: Washington, DC, USA, 2017.

31. Blankespoor, B.; Dasgupta, S.; Laplante, B.; Wheeler, D. Adaptation to Climate Extremes in Developing Countries: The Role of Education; World Bank: Washington, DC, USA, 2010. 
32. Striessnig, E.; Lutz, W.; Patt, A.G. Effects of Educational Attainment on Climate Risk Vulnerability. Available online: https: //www.ecologyandsociety.org/vol18/iss1/art16/ (accessed on 16 August 2021).

33. Podesta, J. The Climate Crisis, Migration, and Refugees; Brookings Institution: Washington, DC, USA, 2019.

34. Jordan, J.C. Deconstructing Resilience: Why Gender and Power Matter in Responding to Climate Stress in Bangladesh. Available online: https:/ / www.tandfonline.com/doi/abs/10.1080/17565529.2018.1442790 (accessed on 16 August 2021).

35. Morales-Doyle, D. Justice-centered science pedagogy: A catalyst for academic achievement and social transformation. Sci. Educ. 2017, 101, 1034-1060. [CrossRef]

36. Carnie, T.L.; Berry, H.L.; Blinkhorn, S.A.; Hart, C.R. In their own words: Young people's mental health in drought-affected rural and remote NSW. Aust. J. Rural Health 2011, 19, 244-248. [CrossRef] [PubMed]

37. Convery, I.; Balogh, R.; Carroll, B. Getting the kids back to school: Education and the emotional geographies of the 2007 Hull floods. J. Flood Risk Manag. 2010, 3, 99-111. [CrossRef]

38. Kelman, I.; Mercer, J.; Gaillard, J.C. The Routledge Handbook of Disaster Risk Reduction Including Climate Change Adaptation; Routledge: London, UK, 2017.

39. Nche, G.C.; Achunike, H.C.; Okoli, A.B. From climate change victims to climate change actors: The role of eco-parenting in building mitigation and adaptation capacities in children. J. Environ. Educ. 2019, 50, 131-144. [CrossRef]

40. Faustini, P. The Challenges of Climate Change: Children on the Front Line; Unicef, United Nations Children's Fund: New York, NY, USA, 2014

41. Roberts, D.A. Competing visions of scientific literacy: The influence of a science curriculum policy image. In Exploring the Landscape of Scientific Literacy; Linder, L., Östman, D.A., Roberts, P.O., Wickman, G., Erickson, A., Eds.; Routledge: London, UK, 2011; pp. 11-27.

42. Aikenhead, G. Expanding the research agenda for scientific literacy. In Promoting Scientific Literacy: Science Education Research in Transaction; Linder, C., Ed.; Geotryckeriet: Uppsala, Sweden, 2007.

43. Sjöström, J.; Eilks, I. Reconsidering different visions of scientific literacy and science education based on the concept of Bildung. In Cognition, Metacognition, and Culture in STEM Education; Springer: Cham, Switzerland, 2018; pp. 65-88.

44. Sørvik, G.O.; Mork, S.M. Scientific literacy as social practice: Implications for reading and writing in science classrooms. Nord. Stud. Sci. Educ. 2015, 11, 268-281. [CrossRef]

45. UN General Assembly, Transforming Our World: The 2030 Agenda for Sustainable Development, 21 October 2015. Available online: https: / /www.refworld.org/docid/57b6e3e44.html (accessed on 30 April 2021).

46. Kamau, M.; Chasek, P.; O'Connor, D. Transforming Multilateral Diplomacy: The Inside Story of the Sustainable Development Goals; Routledge: London, UK, 2018.

47. Gong, Q.; Duan, Y.; Guo, F. Disaster risk reduction education in school geography curriculum: Review and outlook from a perspective of China. Sustainability 2021, 13, 3963. [CrossRef]

48. Koehler, G. Tapping the Sustainable Development Goals for progressive gender equity and equality policy? Gend. Dev. 2016, 24, 53-68. [CrossRef]

49. Razavi, S. The 2030 Agenda: Challenges of Implementation to attain Gender Equality and Women's Rights. Gend. Dev. 2016, 24, 25-41. [CrossRef]

50. Abelenda, A.I. A feminist perspective on the post-2015 Development Agenda. Equal. Rights Rev. 2014, 13, 117-128.

51. Stuart, E.; Woodroffe, J. Leaving no-one behind: Can the Sustainable Development Goals succeed where the Millennium Development Goals lacked? Gend. Dev. 2016, 24, 69-81. [CrossRef]

52. Béné, C.; Newsham, A.; Davies, M.; Ulrichs, M.; Godfrey-Wood, R. Review article: Resilience, poverty and development. J. Int. Dev. 2014, 26, 598-623. [CrossRef]

53. Caraka, R.E.; Lee, Y.; Chen, R.C.; Toharudin, T.; Gio, P.U.; Kurniawan, R.; Pardamean, B. Cluster around latent variable for vulnerability towards natural hazards, non-natural hazards, social hazards in West Papua. IEEE Access 2021, 9, 1972-1986. [CrossRef]

54. Cook, D.A.; West, C.P. Conducting systematic reviews in medical education: A stepwise approach. Med. Educ. 2012, 46, 943-952. [CrossRef]

55. UNESCO. UNESCO Moving forward the 2030 Agenda for Sustainable Development; UNESCO: Paris, France, 2017.

56. Trajber, R.; Walker, C.; Marchezini, V.; Kraftl, P.; Olivato, D.; Hadfield-Hill, S.; Zara, C.; Fernandes Monteiro, S. Promoting climate change transformation with young people in Brazil: Participatory action research through a looping approach. Action Res. 2019, 17, 87-107. [CrossRef]

57. Ahmed, J.U.; Ashikuzzaman, N.M.; Nisha, N. Understanding operations of floating schools: A case of Shidhulai Swanirvar Sangstha in Bangladesh. South Asian J. Bus. Manag. Cases 2016, 5, 221-233. [CrossRef]

58. AhbiRami, R.; Zuharah, W.F. School-based health education for dengue control in Kelantan, Malaysia: Impact on knowledge, attitude and practice. PLoS Negl. Trop. Dis. 2020, 14, e0008075. [CrossRef] [PubMed]

59. Ruiz-Cortés, N.S.; Alcántara-Ayala, I. Landslide exposure awareness: A community-based approach towards the engagement of children. Landslides 2020, 17, 1501-1514. [CrossRef]

60. Vásquez, A.; Marinkovic, K.; Bernales, M.; León, J.; González, J.; Castro, S. Children's views on evacuation drills and school preparedness: Mapping experiences and unfolding perspectives. Int. J. Disaster Risk Reduct. 2018, 28, 165-175. [CrossRef] 
61. Carone, M.T.; Marincioni, F. From tale to reality: Geographical differences in children's flood-risk perception. Area 2020, 52, 116-125. [CrossRef]

62. Ribeiro, A.S.; Silva, I. Drawing on fire: Children's knowledge and needs after a wildfire disaster in Portugal. Child. Geogr. 2020, 18, 726-738. [CrossRef]

63. Sharpe, J.; Izadkhah, Y.O. Use of comic strips in teaching earthquakes to kindergarten children. Disaster Prev. Manag. 2014, 23, 138-156. [CrossRef]

64. Piangiamore, G.L.; Musacchio, G.; Pino, N.A. Natural hazards revealed to children: The other side of prevention. Geol. Soc. Lond. Spec. Publ. 2015, 419, 171-181. [CrossRef]

65. Gampell, A.; Gaillard, J.C.; Parsons, M.; Le Dé, L. Fostering student participation in disaster risk reduction through disaster video games. Aust. J. Emerg. Manag. 2020, 35, 43-50.

66. Musacchio, G.; Falsaperla, S.; Bernhardsdóttir, A.E.; Ferreira, M.A.; Sousa, M.L.; Carvalho, A.; Zonno, G. Education: Can a bottom-up strategy help for earthquake disaster prevention? Bull. Earthq. Eng. 2016, 14, 2069-2086. [CrossRef]

67. Piangiamore, G.L.; Musacchio, G. Participatory approach to natural hazard education for hydrological risk reduction. In Advancing Culture of Living with Landslides; Sassa, K., Mikoš, M., Yin, Y., Eds.; Springer: Cham, Switzerland, 2017.

68. Amri, A.; Bird, D.K.; Ronan, K.; Haynes, K.; Towers, B. Disaster risk reduction education in Indonesia: Challenges and recommendations for scaling up. Nat. Hazards Earth Syst. Sci. 2017, 17, 595-612. [CrossRef]

69. Bernhardsdottir, A.E.; Musacchio, G.; Ferreira, M.A.; Falsaperla, S. Informal education for disaster risk reduction. Bull. Earthq. Eng. 2016, 14, 2105-2116. [CrossRef]

70. De Mendonca, M.B.; Da Silva Rosa, T.; Rosa Bello, A. Transversal integration of geohydrological risks in an elementary school in Brazil: A disaster education experiment. Int. J. Disaster Risk Reduct. 2019, 39, 101213. [CrossRef]

71. Kaiser, L.; Boersen, K. Kura e Tai Aniwhaniwha (schools and tsunami): Bi-cultural and student-centred tsunami education in Aotearoa New Zealand. Aust. J. Emerg. Manag. 2020, 35, 58-65.

72. Shohieb, S.M. CDMG: Crises and disasters management game (video game to teach Arab children how to handle emergencies and crises). In Proceedings of the 2018 7th International Conference on Software and Computer Applications, Kuantan, Malaysia, 8-10 February 2018; pp. 264-268.

73. Williams, A.L.; Bingley, A.; Walker, M.; Mort, M.; Howells, V. “That's where I first saw the water". Mobilizing children's voices in UK flood risk management. Transfers 2017, 7, 76-93. [CrossRef]

74. Tyas, R.A.; Pujianto, S. Integrating Disaster Risk Reduction with Science Education to Student of Junior High School in Merapi Mountain Areas, Indonesia. Int. J. Eng. Res. Technol. 2020, 13, 4551-4557.

75. Nikolaraisi Argyropoulos, V.; Gounari, N.; Valoumas, G. The Role of Children in Disaster Risk Reduction Policies: A Case Study with Hearing and Hard of Hearing Children. 2016. Available online: https://www.slideshare.net/GRFDavos/the-role-ofchildren-in-disaster-risk-reduction-policies-a-case-study-with-hearing-and-hard-of-hearing-children-magda-nikolaraizi (accessed on 16 August 2021).

76. Muzenda-Mudavanhu, C.; Manyena, B.; Collins, A.E. Disaster risk reduction knowledge among children in Muzarabani District, Zimbabwe. Nat. Hazards 2016, 84, 911-931. [CrossRef]

77. Medina, M.A.; Moraca, J.M. Should I stay or should I go? Determinants of evacuation upon flood warning among households in a flood prone area in Bukidnon, Philippines. Int. Lett. Nat. Sci. 2016, 50, 70-75. [CrossRef]

78. Yasuda, M.; Muramoto, T.; Nouchi, R. Assessment of educational methods for improving children's awareness of tsunamis and other natural disasters: Focusing on changes in awareness and regional characteristics in Japan. Geosciences 2018, 8, 47. [CrossRef]

79. Cui, K.; Han, Z.; Wang, D. Resilience of an earthquake-stricken rural community in Southwest China: Correlation with disaster risk reduction efforts. Int. J. Environ. Res. Public Health 2018, 15, 407. [CrossRef]

80. Selby, D.; Kagawa, F.; Oberman, R. Along the cays and bays: Climate change learning in a small island developing state. Policy Pract. A Dev. Educ. Rev. 2020, 30, 31-56.

81. McDonald-Harker, C.; Bassi, E.M.; Haney, T.J. We Need to Do Something about This: Children and Youth's Post-Disaster Views on Climate Change and Environmental Crisis. Available online: https://onlinelibrary.wiley.com/doi/abs/10.1111/soin.12381 (accessed on 16 August 2021).

82. Bandrova, T.; Kouteva, M.; Pashova, L.; Savova, D.; Marinova, S. Conceptual framework for educational disaster centre "Save the children's life". Int. Arch. Photogramm. Remote Sens. Spatial Inf. Sci. 2015, 40, 225-234. [CrossRef]

83. Burke, S.E.; Sanson, A.V.; Van Hoorn, J. The psychological effects of climate change on children. Curr. Psychiatry Rep. 2018, 20, 35. [CrossRef]

84. Clayton, S.; Manning, C.; Krygsman, K.; Speiser, M. Mental Health and Our Changing Climate: Impacts, Implications, and Guidance; American Psychological Association \& ecoAmerica: Washington, DC, USA, 2017.

85. Krishna, R.N.; Ronan, K.R.; Alisic, E. Children in the 2015 South Indian floods: Community members' views. Eur. J. Psychotraumatol. 2018, 9, 1486122. [CrossRef] [PubMed]

86. Paci-Green, R.; Varchetta, A.; McFarlane, K.; Iyer, P.; Goyeneche, M. Comprehensive school safety policy: A global baseline survey. Int. J. Disaster Risk Reduct. 2020, 44, 101399. [CrossRef]

87. Cabrera-Flores, M.; López-Leyva, J.; Peris-Ortiz, M.; Orozco-Moreno, A.; Francisco-Sánchez, J.; Meza-Arballo, O. A framework of penta-helix model to improve the sustainable competitiveness of the wine industry in Baja California based on innovative natural resource management. In E3S Web of Conferences; EDP Sciences: Ulis, France, 2020; Volume 167, p. 06005. [CrossRef] 
88. Caraka, R.E.; Noh, M.; Chen, R.-C.; Lee, Y.; Gio, P.U.; Pardamean, B. Connecting Climate and Communicable Disease to Penta Helix Using Hierarchical Likelihood Structural Equation Modelling. Symmetry 2021, 13, 657. [CrossRef]

89. McAdam, M.; Debackere, K. Beyond 'triple helix' toward 'quadruple helix' models in regional innovation systems: Implications for theory and practice. $R$ D Manag. 2018, 48, 3-6. [CrossRef]

90. Calzada, I. Democratising Smart Cities? Penta-Helix Multistakeholder Social Innovation Framezork. Smart Cities 2020, 3, 1145-1172.

91. Kwauk, C. Roadblocks to Quality Education in a Time of Climate Change; Brookings Institution: Washington, DC, USA, 2020.

92. Reid, R. Climate change education and research: Possibilities and potentials versus problems and perils? Environ. Educ. Res. 2019, 25, 767-790. [CrossRef] 